Volume 1 Issue 3, 2021, 48-55 EXPERT

\author{
Journal Homepage: https://journalofforensicexpert.id
}

e-ISSN: 2808-5248

PUSLABFOR BARESKRIM POLRI

\title{
ANALISA BENTUK PEMALSUAN TANDA TANGAN PADA DOKUMEN
}

\author{
Rochani, Rian Aprilian, Eri Hermansyah, Fatih Rakhmawati* \\ Puslabfor Bareskrim Polri, Indonesia \\ ${ }^{*}$ Correspondence E-mail: fatihrakhmawati17@gmail.com
}

\begin{tabular}{l}
\hline ARTICLE INFO \\
\hline Article history: \\
Received 21 August 2021 \\
Revised 22 September 2021 \\
Accepted 25 Oktober 2021 \\
Available online 19 Oktober 2021 \\
\hline Keywords: evidence, signature, \\
forensic \\
Kata kunci: barang bukti, tanda \\
tangan, forensik \\
\hline DOI: \\
https://doi.org/10.54579/jfe.v1i3.5
\end{tabular}

How to Cite :

Rochani, Aprilian, R., Hermansyah, E., Rakhmawati, F. (2021). Analisa Bentuk Pemalsuan Tanda Tangan pada Dokumen. Journal of Forensic Expert, 1(3), 48-55.

\begin{abstract}
Graphonomy is an interdisciplinary field that is directed at the scientific analysis of the process of writing and signatures, the results of scratches, and other graphic skills on documents that lead to the examination of writing for identification purposes to serve law enforcement and justice. Analysis of the form of signatures on documents using the forensic identification method is divided into 3 forms that produce differences in crossing, touch (pressure), ink, and pulling edges, where the principle of signature examination is to compare the evidence with the original comparison of the victim. The examination will produce a different analysis from each examiner's view seen from the form of the signature, so that the examiner must recognize all parts of the writing or signature that have a strong characteristic of permanent content in a document to be examined.
\end{abstract}

\section{ABSTRAK}

Grafonomi merupakan suatu bidang interdisiplin ilmu yang diarahkan pada analisis ilmiah proses tulisan dan tanda tangan, hasil goresan, serta keterampilan grafis lainnya pada dokumen yang mengarah pada pemeriksaan tulisan untuk tujuan identifikasi guna melayani penegakan hukum dan peradilan. Analisa bentuk tanda tangan pada dokumen yang menggunakan metode identifikasi forensik terbagi menjadi 3 bentuk yang menghasilkan perbedaan pada crossing, touch (tekanan), tinta, dan tepian tarikan, dimana prinsip dari pemeriksaan tanda tangan yaitu membandingkan antara barang bukti dengan pembanding asli dari korban. Dalam pemeriksaan akan menghasilkan analisa yang berbeda dari setiap pandangan pemeriksa yang dilihat dari bentuk tanda tangan tersebut, sehingga pemeriksa harus mengenal semua bagian tulisan atau tanda tangan yang memiliki ciri khas unsur kadar permanen yang kuat dalam suatu dokumen yang akan diperiksa. 


\section{Pendahuluan}

Grafonomi merupakan suatu bidang interdisiplin ilmu yang diarahkan pada analisis ilmiah proses tulisan dan tanda tangan, hasil goresan, serta keterampilan grafis lainnya (Sibarani,E, Grafonomi. 1970). Dalam grafonomi dapat menganalisis otentifikasi (keaslian) suatu tulisan dan tanda tangan, apakah dibuat oleh seseorang yang sama atau dibuat oleh orang lain (dipalsukan) (Mulachela, Syibly Avivy A. 2020). Grafonomi berbeda dengan grafologi, grafologi pertama kali disebut pada tahun 1830 oleh Jean-Hipopolyte Michon, seorang arkeolog dan pendeta dari perancis, ia tertarik dengan analisis tulisanan tangan dan mengemukakan idenya tentang "tafsir tulisan tangan" itu dengan coretan tangan Abbe Flandrin, Grafologi berbeda dengan psikologi, grafologi hanya dapat mendeteksi karakter dan menganalisisnya secara umum sesuai dengan indikator, namun grafologi dan psikologi tak dapat dipisahkan, karena untuk memahami grafologi harus memahami psikologi dasarnya terlebih dahulu, dimana di dalam ilmu grafologi pemeriksaan tanda tangan atau tulisan tangan bertujuan untuk mengetahui watak atau sifat seseorang, sedangkan didalam ilmu grafonomi bertujuan untuk mengetahui ciri-ciri karakteristik yang terdapat didalam tulisan tangan dan tanda tangan tersebut (Mend, Karen Kristin \& Ruiz, Mary Stansbury. 2011).

Kejahatan pemalsuan dokumen di Indonesia termasuk kejahatan yang presentasinya tinggi, hal ini didasarkan dari data perkara yang masuk tiap tahun ke Pusat Laboratorium Forensik Polri mengenai pemeriksaan kasus pemalsuan dokumen yaitu sekitar 200-300 kasus pertahun untuk wilayah pelayanan Jakarta, Banten dan Jawa Barat;(Data Perkara Bid Dokupalfor Puslabfor Bareskrim Polri tahun, 2020)

Kasus - kasus kejahatan dokumen yang terjadi menyangkut pengikatan jual beli, pembagian ahli waris, kesepakatan bersama bahkan terkait dengan kasus pembunuhan dimana biasanya ditemukan dokumen berupa surat wasiat di tempat kejadian perkara yang dapat dijadikan petunjuk apakah dokumen tersebut dibuat oleh korban atau ada pelaku lain yang membuat dokumen tersebut tetapi seolah-olah dibuat oleh korban. Perbuatan pemalsuan dokumen ini dapat diartikan sebagai suatu tindakan seseorang yang memberikan gambaran atas suatu barang atau surat seolah-olah asli atau benar, sedangkan keadaan barang atau surat itu sesungguhnya tidak benar atau tidak asli. Dalam KUHP ketentuan-ketentuan yang berhubungan dengan kejahatan pemalsuan dokumen termuat dalam pasal 263 (Wibawa, Heru Kustriadi. 2002) yaitu:

a. Pasal 263 ayat 1 “ Barang siapa membuat surat palsu atau memalsukan surat yang dapat menerbitkan suatu hak, sesuatu perutangan, membebaskan utang atau yang dapat dipergunakan untuk bukti suatu hak dengan maksud untuk memakai atau menyuruh orang lain memakai surat itu solah-olah surat itu asli atau tidak dipalsukan, jika pemakaian surat itu mendatangkan kerugian maka karena pemalsuan surat dihukum dengan hukuman penjara selama-lamanya 6 tahun;

Dari pasal 263 ayat 1 menyatakan dua jenis perbuatan yaitu (a) membuat surat palsu dan

(b) memalsukan surat.

1) Membuat suarat palsu 
Rochani, Aprilian, R., Hermansyah, E., Rakhmawati, F. Analisa Bentuk Pemalsuan Tanda Tangan...

Membuat surat palsu adalah menyusun tulisan atau surat secara keseluruhan yang isinya bukan semestinya atau membuat surat sedemikian rupa sehingga surat itu tidak benar. Membuat surat palsu ini dapat mengenai isinya atau tanda tangannya;

2) Memalsukan Surat

Memalsukan surat adalah mengubah surat atau tulisan sedemikian rupa sehingga isinya menjadi lain daripada aslinya. Hal ini dapat dilakukan baik dengan mengubah tanda tangan ataupun isinya yang sudah tentu tanpa seizin dari yang berhak, sehingga hasilnya akan bertentangan atau berlainan dengan yang sebenarnya. Perbuatan ini dilaksanakan dengan cara menambah, mengurangi, menghapus satu atau beberapa kalimat kata, angka, dan tanda tangan. Ini mengakibatkan danya perubahan baik isi maupun tujuannya semula.

b. Pasal 263 ayat 2: dihukum dengan hukuman semacam itu, barang siapa dengan sengaja memakai surat palsu atau surat dipalsukan seolah-olah surat itu asli dan tidak dipalsukan, kalau Dari Pasal 263 ayat 2 ini yang dilarang adalah penggunaan / pemakaian surat palsu atau yang dipalsukan. Unsur kesengajaan juga terdapat dalam pasal ini. Yang dimaksud dengan sengaja adalah bahwa orang yang menggunakannya itu harus mengetahui benarbenar surat yang ia gunakan itu palsu.

Sehingga suatu perbuatan pemalsuan surat yang melanggar pasal 263 ayat 1 dan 2 adalah perbuatan membuat surat secara palsu dan memalsukan surat maupun menggunakan surat yang dipalsukan tersebut.

Dokumen adalah suatu tulisan atau gambar yang terdapat pada alas atau tempat tertentu yang dapat dijadikan sebagai alat bukti (Sibarani,E, Grafonomi. 1970). Pemeriksaan dokumen dapat mencakup semua hal yang terdapat didalam dokumen tersebut seperti blanko dan fiturfitur pengamannya, tulisan-tulisan yang terdapat di permukaannya, cap stempel dan tanda tangan, sehingga verifikasi dokumen akan menyangkut hal-hal tersebut. Tanda tangan sebagai suatu tanda atau nama terang yang dibubuhkan seseorang sebagai tanda untuk menyetujui isinya (Sibarani,E, Grafonomi. 1970). Tanda tangan ada beberapa jenis yaitu tanda tangan Basah, tanda tangan Cap Stempel, tanda tangan Produk cetak printer dan tanda tangan foto copy. Dengan demikian, dokumen-dokumen tertentu diharuskan untuk menggunakan tanda tangan asli atau basah sehingga apabila ditemukan tanda tangan yang bukan merupakan tanda tangan asli atau basah maka dokumen tersebut tidak sah dan melanggar pasal 263 KUHPidana mengenai pemalsuan surat.

\section{Metode}

Sampel

Sampel dalam penelitian ini adalah barang bukti yang diterima oleh laboratorium forensik. Sampel dibagi kedalam tiga kelompok jenis bentuk tanda tangan, yaitu tanda tangan asli atau basah, tanda tangan produk cetak printer dan tanda tangan foto copy (Moleong, Lexy J. 2007). 


\section{Pemeriksaan sampel barang bukti}

Pemeriksaan tanda tangan pada prinsipnya adalah membandingkan (Found, B., \& Rogers, D. 1999). Membandingkan 3 buah dokumen yang memiliki tanda tangan asli atau basah, tanda tangan produk cetak printer dan tanda tangan foto copy dengan menggunakan alat VSC $8000 \mathrm{HS}$ dan Microskop Digital baik stationer maupun portable. Dalam pemeriksaan ada 4 unsur yang dijadikan acuan yaitu:

1. Crossing tanda tangan yaitu menentukan perpotongan tanda tangan yang diperiksa kemudian diperbesar dengan perbesaran tertentu sampai terlihat jelas garis pada perpotongan tersebut yang dibuat terlebih dahulu (Ellen, David. 2018).

2. Touch atau tekanan tanda tangan yaitu dengan menggunakan sinar samping yang dapat memperlihatkan tekanan suatu tanda tangan (Ellen, David. 2018).

3. Kepadatan tinta yaitu dengan perbesaran tertentu dapat terlihat kepadatan tinta dan homogenitas tinta (Kippan, Helmut. 2001).

4. Tepian tanda tangan yaitu dengan perbesaran tertentu tepian tanda tangan dapat terlihat lurus ataupun bergelombang (Kippan, Helmut. 2001).

\section{Hasil dan Pembahasan}

\section{Hasil}

Pemeriksaan tanda tangan yang meliputi 4 unsur yaitu:

\section{Crossing Tanda Tangan}

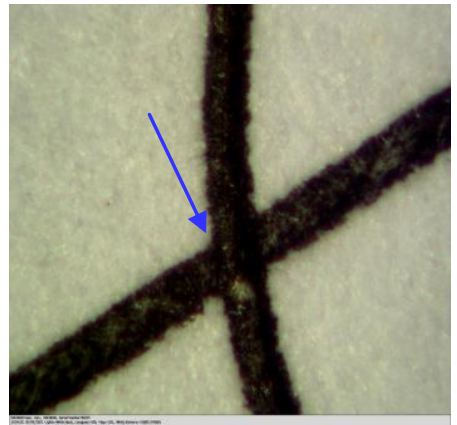

a

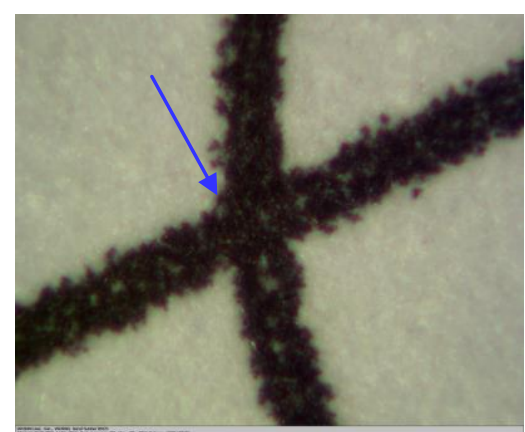

$\mathrm{b}$

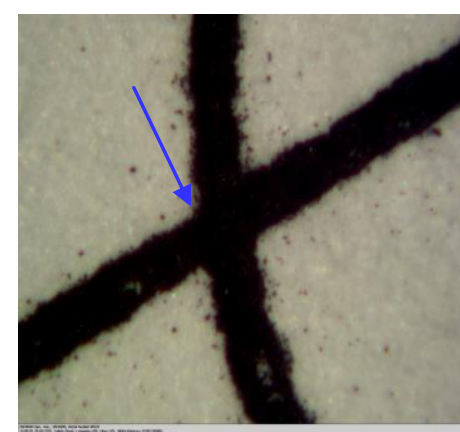

C

Gambar 1. Crossing tanda tangan dengan menggunakan VSC 8000 perbesaran 128x pada a) tanda tangan asli atau basah, b) tanda tangan produk cetak printer, c) tanda tangan foto copy.

Pada pemeriksaan ini dapat menentukan tarikan pertama dan kedua tanda tangan. Tanda tangan asli atau basah terlihat jelas perpotongan tarikan sedangkan tanda tangan produk cetak printer dan tanda tangan foto copy tidak terlihat jelas sehingga tidak dapat menentukan tarikan pertama dan kedua tanda tangan (Osborn, Albert S. 1954). 


\section{Touch Tanda Tangan}

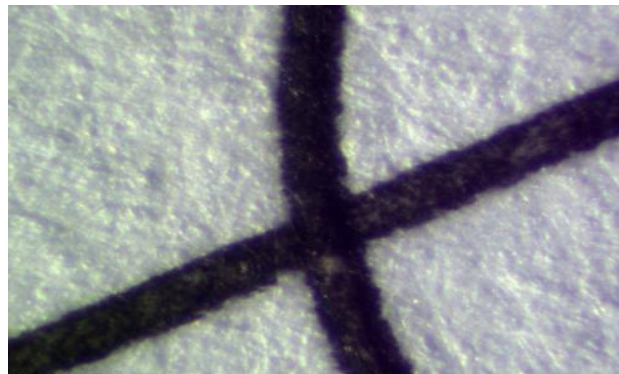

a

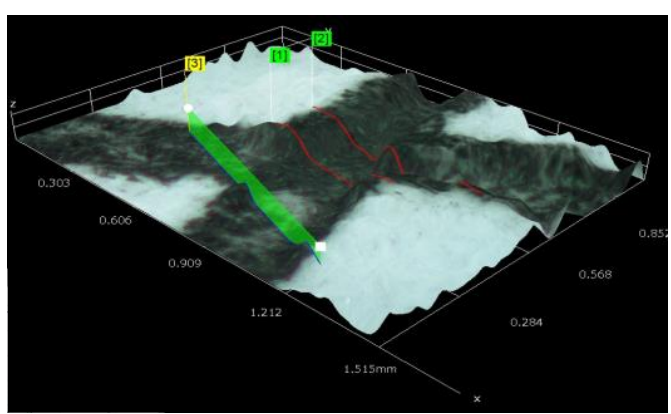

$\mathrm{b}$

Gambar 2. Touch tanda tangan asli atau basah dengan menggunakan a) VSC 8000 dan b) Hirox 3D digital microscop

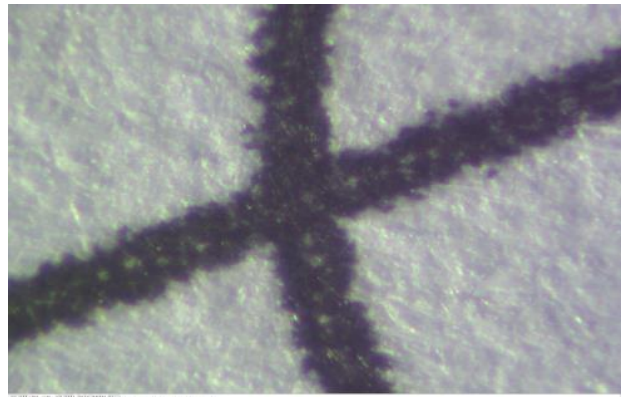

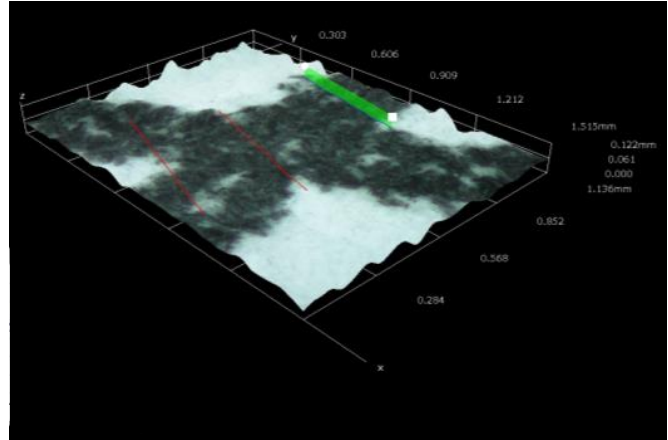

b

Gambar 3. Touch tanda tangan produk cetak printer dengan menggunakan a) VSC 8000 dan b) Hirox $3 \mathrm{D}$ digital microscop

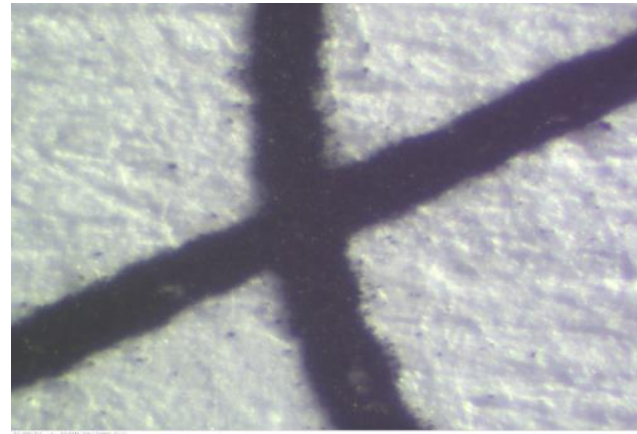

a

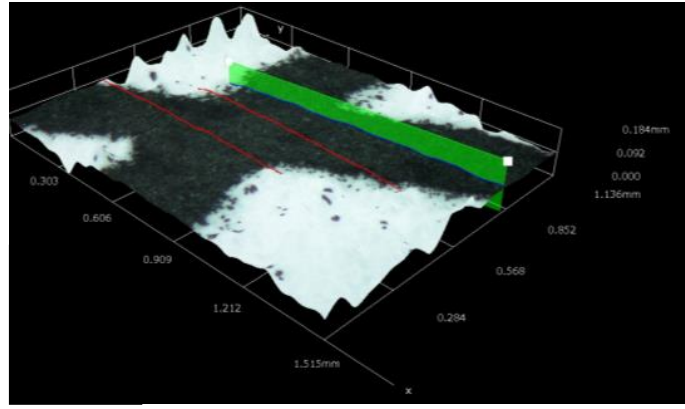

$\mathrm{b}$

Gambar 4. Touch tanda tangan foto copy dengan menggunakan a) VSC 8000 dan b) Hirox 3D digital microscop.

Pemeriksaan dengan menggunakan Video Miskroskop Digital terlihat secara 3D lekukan pada tekanan tanda tangan asli atau basah, dimana bagian kertas berwarna putih lebih tinggi dibanding dengan bagian tinta yang berwarna hitam. Hal tersebut menunjukkan bahwa saat seseorang membubuhkan tanda tangan secara langsung maka terdapat tekanan dari pena atau alat tulis pada kertas atau alas, sedangkan tekanan tanda tangan produk cetak printer terlihat sama antara permukaan kertas yang berwarna putih dengan tinta yang berwarna hitam (Slyter, Steven A. 1995). Pada tanda tangan foto copy juga terlihat permukaan kertas bagian putih sejajar dengan 
bagian tinta yang berwarna hitam, tetapi pada bagian tertentu terlihat bahwa bagian tinta lebih tinggi diatas permukaan kertas bagian putih, hal ini disebabkan karena mesin foto copy menggunakan tinta toner yang dipanaskan dan menempel ke bagian kertas, sehingga mengakibatkan bagian tinta warna hitam terlihat lebih tinggi dari pada permukaan kertas (Kippan, Helmut. 2001). Berdasarkan pengukuran gambar 2, 3, dan 4 diatas, akan ditampilkan kedalaman tekanan antara tanda tangan asli atau basah, tanda tangan hasil produk cetak printer dan tanda tangan foto copy adalah sebagai berikut:

Tabel 1. Point Heigth tanda tangan

\begin{tabular}{cccc}
\hline No. & $\begin{array}{c}\text { Tanda tangan asli atau } \\
\text { basah }\end{array}$ & $\begin{array}{c}\text { Tanda tangan hasil produk cetak } \\
\text { printer }\end{array}$ & $\begin{array}{c}\text { Tanda tangan foto } \\
\text { copy }\end{array}$ \\
\hline $\mathbf{1 .}$ & $0,087 \mathrm{~mm}$ & $0,011 \mathrm{~mm}$ & $0,028 \mathrm{~mm}$ \\
2. & $0,090 \mathrm{~mm}$ & $0,010 \mathrm{~mm}$ & $0,024 \mathrm{~mm}$ \\
3. & $0,071 \mathrm{~mm}$ & $0,008 \mathrm{~mm}$ & $0,020 \mathrm{~mm}$ \\
\hline
\end{tabular}

Dari Tabel 1 Point Height tanda tangan diatas dapat terlihat bahwa tanda tangan asli atau basah mempunyai nilai point height tertinggi yaitu $0.09 \mathrm{~mm}$ sedangkan tanda tangan hasil produk cetak printer mempunyai point height yang terendah yaitu $0,008 \mathrm{~mm}$. Hal ini disebabkan karena tanda tangan asli atau basah dalam proses pembuatannya terjadi penekanan pada tarikantarikan tanda tangannya sedangkan tanda tangan hasil produk cetak printer tidak ada tekanan dan tinta printer yang tercetak menyerap ke kertas sehingga terlihat sama datar antara permukaan kertas dan tinta.

Pada tanda tangan foto copy juga tidak ada tekanan sehingga nilainya lebih kecil dibanding tanda tangan asli atau basah, tetapi nilai point height tanda tangan foto copy lebih besar dibandingkan dengan tanda tangan tangan hasil produk cetak printer. Hal ini seperti dijelaskan diatas bahwa prinsip kerja mesin foto copy adalah memanaskan tinta toner keatas kertas kemudian akan tercetak dokumen sesuai yang diperintahkan, hal ini menyebabkan bagian tinta memiliki point heigt lebih tinggi dibanding permukaan kertas karena ada penumpukan tinta toner yang tercetak diatas kertas.

\section{Kepadatan Tinta}

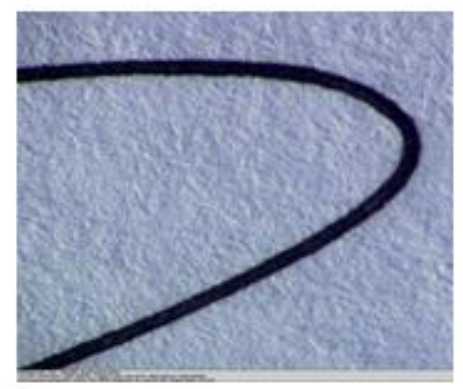

a

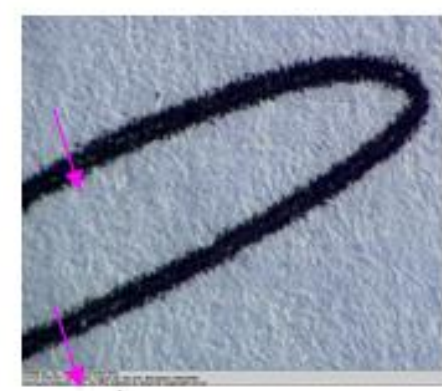

b

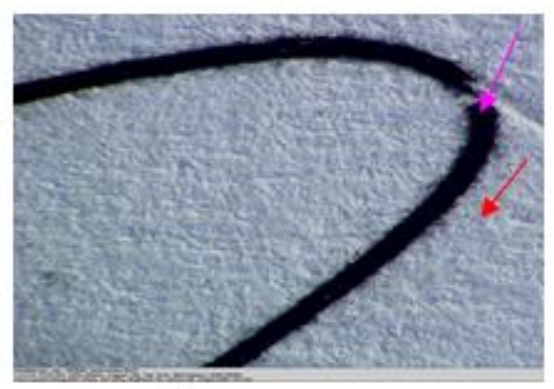

c

Gambar 5. Kepadatan tanda tangan dengan menggunakan VSC 8000 perbesaran 128x pada a) tanda tangan asli atau basah, b) tanda tangan produk cetak printer, dan c) tanda tangan foto copy

Kepadatan tinta pada tanda tangan asli atau basah mempunyai kerapatan yang homogen, sedangkan tanda tangan hasil produk cetak printer terdapat bagian yang kosong (rongga) seperti 
yang ditunjukkan oleh panah berwarna ungu. Pada tanda tangan foto copy, terdapat banyak bagian kosong di dalam tarikan tanda tangannya (panah warna ungu) dan bagian di sekitar tanda tangan terdapat bintik-bintik (dot) warna hitam akibat tinta toner mesin foto copy (panah warna merah).

\section{Tepian Tanda Tangan}

Tepian tanda tangan asli atau basah terlihat lurus sedangkan produk cetak printer dan foto copy terlihat bergelombang yang signifikan

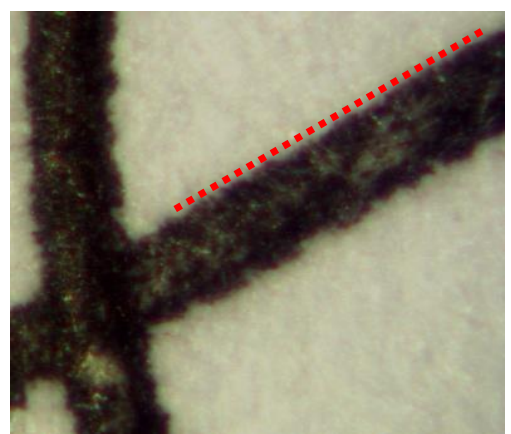

a

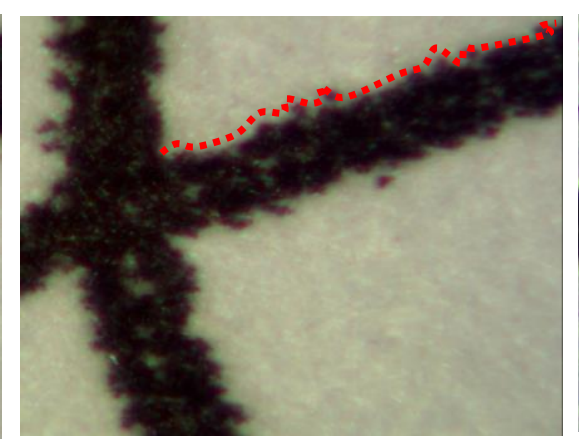

b

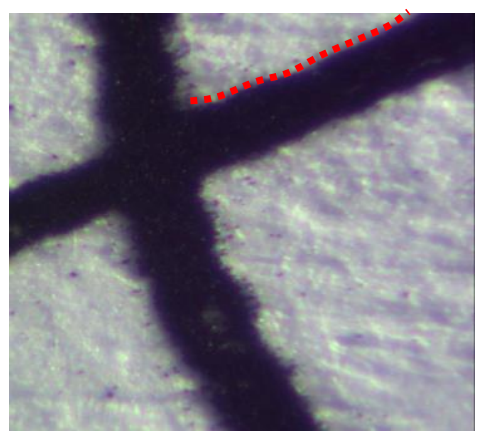

C

Gambar 6. Tepian tanda tangan dengan menggunakan VSC 8000 perbesaran 128x pada a) tanda tangan asli atau basah, b) tanda tangan produk cetak printer, dan c) tanda tangan foto copy

\section{Penutup}

Berdasarkan penelitian ini, disimpulkan bahwa pemeriksaan dokumen pada barang bukti dengan perbedaan bentuk pemalsuan tanda tangan asli atau basah, tanda tangan hasil produk cetak printer dan tanda tangan fotocopy dilihat pada crossing, touch (tekanan), tinta, dan tepian tarikan. Pada bentuk tanda tangan asli atau basah terlihat crossing, touch, tinta penuh dan tepian yang lurus sedangkan tanda tangan hasil produk cetak printer dan fotocopy tidak terlihat crossing, touch, dan terdapat rongga kosong pada tinta di beberapa titik serta tepian yang bergelombang.

Dalam penelitian ini masih dapat dikembangkan lebih lanjut. Beberapa saran untuk mengembangkan penelitian ini adalah pengumpulan dokumen dari data perkara lama yang memiliki perbedaan tekstur tinta sehingga dapat dijadikan acuan dalam menganalisa suatu tarikan tanda tangan pada dokumen.

\section{Daftar Pustaka}

Amend, Karen Kristin \& Ruiz, Mary Stansbury. (2011). Hand writing analysis. Jakarta: PT. Bhuana Ilmu Populer.

Ellen, David. (2018). The scientific examination of documents methods and Techniques. Boca Raton: CRC Press.

Found, B., \& Rogers, D. (1999). Documentation of forensic hand writing comparison and identification method; A modular approach, Journal of forensic document examination. $12,1-68$. 
Kippan, Helmut. (2001). Handbook of print media. Jerman: Heidelberg.

Moleong, Lexy J. (2007). Metodologi Penelitian Kualitatif. Bandung: Penerbit PT Remaja Rosdakarya Offset.

Mulachela, Syibly Avivy A. (2020). Grafologi forensic. Bandung: LKP Grafologi Indonesia.

Osborn, Albert S. (1954). Questioned documents. New York: Body printing company.

Sibarani,E, Grafonomi. (1970). Sistematika dalam penulisan tanda tangan. Jakarta: BotasupalInpres $1 / 1971$.

Slyter, Steven A. (1995). Forensic signature examination. United states of America: Charles C Thomas Publisher.

Wibawa, Heru Kustriadi. (2002). Verifikasi dokumen dan tanda tangan. Jakarta: Gramedia. 